\title{
Wastewaters of meat-processing enterprise: assessment of genotoxic potential
}

\author{
Olga Ivanchenko ${ }^{1, *}$, Rustem Khabibullin ${ }^{2}$, and Rahat Bhat $^{3}$ \\ ${ }^{1}$ Higher School of Biotechnology and Food Technology, Saint Petersburg State Polytechnical \\ University named after Peter the Great, 199005, Politekhnicheskaya Str., 29, St.Petersburg, Russia \\ ${ }^{2}$ Kazan National Research Technological University, 420015, Kazan, K.Marks Str., 68, Russia \\ ${ }^{3}$ Food Science Department,School of Applied Sciences, College of Engineering, Science and \\ Technology,Fiji National University (FNU), Fiji Islands
}

\begin{abstract}
Environmental pollution and ecosystem dysfunction are one of the most important problems of the today's world. Assessment of toxigenic properties of effluents from the meat-processing enterprise was carried out using the short-term microorganisms biotests in vitro. Both native waste water and its ether and water fractions were investigated. The probes' sterilization was carried out by filtration through the sterile membrane filters Synpor with pores diameter of $0.45-\mathrm{m}$. Mutagenic activity of wastewaters was determined using the Salmonella/microsomes plate with in vitro metabolic activation and without metabolic activation (Ames test). As a metobolic activation the rat liver microsomes were used. Studying of the DNA-damaging activity was carried out using the suspension method modification on the mutant Escherichia coli strains, in which the functioning of one reparation systems is suppressed: uvrA', recA- and pol $\mathrm{A}^{-}$. Native waste water doesn't have an influence on the mutant strains rec $\mathrm{A}^{-}$and pol $\mathrm{A}^{-}$, its survivability degree is in the range $96-100 \%$. However, DNA-damaging action was registered for the strain with the damaged excision repair ( uvrA $^{-}$), survivability of which was $81.31 \%$. Ames test of wastewater and its fractions didn't reveal any mutagenic activity. The tests used in this work allow one to comprehensively estimate the genetic danger of the enterprise wastewaters within a short time and are recommended as test-systems for monitoring the ecological safety of wastewaters.
\end{abstract}

\section{Introduction}

Food production enterprises, including meat-processing ones are the sources of antropogenic and technogenic impact of its wastewaters on the natural water bodies. Development of technologies for purification and utilization of industrial wastes requires usage of express-tests, which allow one to obtain fast and qualitative characterization of wastes and wastewaters [1-11].

As for now, wastewater quality is controlled according to its bacterilogical, chemical and parasitological characteristics, which can't be evaluated in a short time. In the majority

*Corresponding author: obivanchenko@yandex.ru 
of cases the safety is determined by the allowable concentrations, which were developed for certain chemical substances. At the same time in nature the organism is affected by a complex of substances (not separate ones) which, having and influence one on another, can increase or decrease the total impact. So, water quality assessment using the integral characteristics appears to be the most perspective approach to understanding the real ecological safety of wastewaters [12-14].

At the system of monitoring the natural environments and ecosystems conditions the most important and outstanding role is now placed for the biotesting in various test objects [15-18]. As an object of investigation one may choose microorganisms, protozoans, plants, fishes, etc. Nowadays it is difficult to prefer one and a certain object, so in each specific case the researcher should select those which conform to the declared task or use a set of tests [19-21].

Alongside with this, assessment of toxicity level doesn't show in a full extent dangerous, especially, toxigenetic, consequences of the natural objects pollution. It is because the highest hazard to health of the present and future generations consists in compounds, which are able to produce the delayed actions: mutagens and cancerogenes. The recommended by the existing normatives evaluation of toxicity cannot replace the genotoxicity evaluation in special tests, because these characteristics don't correlate directly. Besides this, such investigations are feasible at safety monitoring of wastewaters, supplied at biological waste treatment facilities in order to prevent penetration of hazardous materials into the biocenoses of active sludge. So, investigation of the total mutagenic activity is the most perspective approach to revealing mutagenic potential of wastewater.

Investigations of wastewater mutagenic properties of various industrial enterprises using test-systems of various organization types, aimed at practical justification the necessity for genotoxicity analysis for the complex assessment of wastewater safety are carried out both in Russia and other countries [22-26].

Microorganisms are often used as test-objects for genetic investigations. It is caused by the fact that they are simply stored and rapidly multiply, which allows one to obtain the results in short time and without large expenses. In this connection the microbial Ames test is widely used as one of the main methods at screening investigations [27]. For taking into account the metabolic activation of mutagens one has developed its modification, which is called Ames Salmonella/microsome plate test. Metabolic activation of mutagens often occurs in microsomes of liver cells of an animal or human under the impact of mixedfunction monooxygenase. In order to in vitro model this process, one should add to the microorganisms' culture medium the microsome fraction (S9) from the liver cells [28,29].

The aim of this work is to investigate the genetic safety of meat-processing enterprise wastewater for the surrounding ecosystems and biocenosis of the biological wastetreatment facilities.

\section{Materials and methods}

In this work we investigated both native wastewater from the meat-processing enterprise (Tatarstan) and its ether and water fractions.

The ether fraction was obtained by wastewater extraction using the diethyl ether with further evaporation of the ether layer to dryness and dissolving of the solid residue in dimethylsulfoxide (DMSO). After the residue dissolving $1 \mathrm{ml}$ of DMSO comprised extract from $5 \mathrm{ml}$ of native wastewater.

Water fraction was the residue of native wastewater after its extraction by ether.

The probes' sterilization was carried out by filtration through the sterile membrane filters Millipore S-Pak (Merck Millipore) with pores diameter of $0.45 \mu \mathrm{m}$. 


\subsection{Test for DNA-damaging activity}

This method is based on selective inhibition of the mutant strains' growth in comparison with the wild type. The assessment was carried out using the mutant Escherichia coli strains, in which the functioning of one reparation systems is suppressed:

$W P$-trp E, whild type.

$u v r A^{-}$- trp 65,sul, uvr A 155 (excisional repair is damaged).

$r e c A^{-}$-trp-65, rec A (post-replicative repair is damaged).

pol $A^{-}$- trp-65, pol $A$ (work of DNA-polymerase 1 is damaged)

We used Rosencrantz suspension modification for compounds weakly diffusing in agar, when the test-culture cells come into direct contact with the examined substance, which allows one to increase the test sensibility. The difference in suspension density, which characterizes the bacteria growth, for the strains with "normal" and repair-defected genotypes states for the presence of activity of the sample under investigation. The bacteria survivability degree of $96-100 \%$ states for the absence of DNA-damaging activity, at 86$96 \%$ the activity is low (boundary). When it is less than $85 \%$ it states for dominating strain death. As a positive control we used water solution of furacilin $(500 \mu \mathrm{g} / \mathrm{ml})$.

Mutagenic activity was determined using the Salmonella/microsomes plate with in vitro metabolic activation and without metabolic activation (Ames test). The experiment were carried out according to Maron and Ames [27], at the Fonstein modification [30]. His modification with metabolic activation allows one to simulate some reactions which occur in mammal organisms involving cytochrome P-450-dependent monooxygenases. Auxotrophic to histidine strain Salmonella typhimurium TA100 (his G 46, rfa, uvr', bio-, $\mathrm{pkm} \mathrm{10)}$ allows one to register mutations of base-pair replacement type. As a positive control we used direct mutagen nitrosomethylurea, and for the experiments with metabolic activation we used benzo[a]pyrene.

The principle of the method is that tester strains of Salmonella typhimurium bacteria are cultivated on a special medium, at which only the revertants can develop, i.e. microorganisms, which had a mutation from auxotrophy for histidine to prototrophy. Spontaneously such mutations occur with low frequency, but if one introduce a chemical mutagene into the cultivation medium, the mutation frequency increases for some orders, which is registered according to the amount of the microorganisms colonies grown at the selective medium.

The lower selective agar medium was poured into the sterile Petrie dishes and incubated for 2 hours at room temperature. We added $0.1 \mathrm{ml}$ of bacterial suspension and $0.1 \mathrm{ml}$ of wastewater to the molten $0.6 \%$ upper agar medium with biotin and histidine cooled up to temperature $38-42{ }^{\circ} \mathrm{C}$. The content of test tube was mixed up and put on the lower selective agar so that the semi-liquid agar covered the surface of the lower minimal agar by a smooth layer. After setting solid the dishes were placed in a thermostat at $37^{\circ} \mathrm{C}$.

The increased histidine content in samplings can be a reason of false-positive results of the Ames test. The histidine dose required for revertants duplicating should be not less than $232 \mu \mathrm{g} / \mathrm{ml}$ [31]. Our analysis has shown that histidine concentration for the examined samples was not more than $100 \mu \mathrm{g} / \mathrm{ml}$.

\section{Results and discussion}

Nowadays safety assessment of wastewaters isn't limited by evaluation of its toxicity. Investigation of the total mutagenic activity, which characterizes integrated influence of the toxicants' complex on the living organisms allows one to evaluate the possibility for appearance of damages in the DNA molecule. The stimulated changes in genome lead to loss of cell properties and this may result in population interchange in biocenose. 
It is known that the majority of DNA damages might be reconstructed by reparation systems. This phenomenon is a base for widespread methods of testing the chemical compositions to the DNA-damaging activity, which is denoted from the selective inhibition of bacterial strains growth, which possess mutations in genes, which control various stages of DNA reparation. These methods, together with tests for mutagenity are successfully used for preliminary detection of mutagens and cancerogenes.

The possibilities of compounds and material complexes which are contained in wastewater to induce the DNA damaging were investigated in a DNA-damaging test using the tester microorganisms strains, which are able to register damages, repairing of which requires functioning of excision or post-replicative systems of DNA-polymerase 1 repair.

The results are presented in Table 1. The experimental data show that native wastewater doesn't have and influence on mutant strains $\operatorname{pol} A^{-}$, rec $A^{-}$, the survivability degree is in the range 96-100\%. However, DNA-damaging activity was registered for the strain with the damaged excision repair, survivability of which was $81.31 \%$.

Table 1. DNA-damaging activity of wastewater

\begin{tabular}{|c|c|c|c|}
\hline \multirow{2}{*}{$\begin{array}{c}\text { Mutant strains } \\
\text { E. coli }\end{array}$} & Native wastewater & Organic fraction & Water fraction \\
\cline { 2 - 4 } pol $A^{-}$ & 98.77 & 94.33 & 96.51 \\
\hline$r e c A^{-}$ & 98.22 & 93.64 & 94.29 \\
\hline$u v r A^{-}$ & 81.31 & 95.70 & 98.90 \\
\hline
\end{tabular}

At the experiment with organic fraction we registered DNA-damaging action of the examined water for all three strains. Water fraction of wastewater didn't have an influence of the mutant strains $\mathrm{polA}^{-}, u v r A^{-}$, but we detected low DNA-damaging activity for the strain rec $A^{-}$. So we came to a conclusion that wastewater fractions individually do not possess strong DNA-damaging action, but the maximum effect was registered in case of native water assessment without fraction division. This permits us to suppose that components of wastewater enhance DNA-damaging action of each other and for repairing these DNA defects the full-value functioning is required, first of all for excision repair .

The results for wastewater mutagenic activity assessment are presented in Table 2. Investigation of wastewaters of meat-processing enterprise, as well as its fractions which possess hydrophilic or lypophilic properties, didn't show any indicators of its mutagenic activity at the Ames test, both in conditions of in vitro metabolic activation by ferments of rat liver cells and without it. Both from biological and hygienic points of view, the optimum method for investigation of total mutagenic activity of complex mixtures (pollutants of waters and soil) is assessment of water extracts mutagenity. It is the water-soluble fraction which introduces a real threat for entering the human organism after washing out into the ground waters passing into plants, etc.

Table 2. Mutagenic activity of wastewater in Salmonella/microsomes Ames test for the strain TA 100

\begin{tabular}{|c|c|c|}
\hline Test variant & Sample under & $\begin{array}{c}\text { Amount of colonies-revertants } \\
\text { in one Petrie dish }\end{array}$ \\
\hline Tests without metabolic & Native drain & $45.0 \pm 1.5$ \\
activation & Organic extract & $47.5 \pm 1.5$ \\
& Water fraction & $62.0 \pm 4.0$ \\
& Negative control & $42.5 \pm 2.5$ \\
& Positive control & $150.0 \pm 12.5$ \\
\hline Tests with metabolic & Native drain & $10.5 \pm 2.5$ \\
activation & Organic extract & $4.5 \pm 0.5$ \\
& Water fraction & $10.5 \pm 0.5$ \\
\hline
\end{tabular}




\begin{tabular}{|c|c|c|}
\hline & Negative control & $8.0 \pm 2.0$ \\
& Positive control & $120.0 \pm 9.0$ \\
\hline
\end{tabular}

Economic pressure from water service companies and regulatory authorities with increased frequency set the goals for the enterprises, which are of search for efficient, reliable waste-treatment facilities, which will guarantee stable high quality of purification, or reconstruction and modernization of the existing facilities. The most appropriate instruments for studying toxicity and mutagenic activity of wastewater are the methods using the nature microorganisms, which allow one to obtain integrated assessment of the impact on ecosystems.

Consequently, the tests used in this work allowed us to comprehensively estimate the genetic danger of the enterprise wastewaters within a short time while choosing a way for its bleeding-off and utilization. These tests are recommended as test-systems for monitoring the ecological safety of wastewaters.

\section{References}

1. A. Khalil, N. Sergeevich,V. Borisova, Adsorption Science and Technology 36(5-6), 1294-1309 (2018)

2. N.A. Politaeva, V.V. Slugin, E.A. Taranovskaya, I.N. Alferov, M.A. Soloviev, A.M. Zakharevich, Izvestiya Vysshikh Uchebnykh Zavedenii, Seriya Khimiya i Khimicheskaya Tekhnologiya 60(7), 85-90 (2017)

3. M.S. Alshabab, M. Andrianova, D. Alsalloum, MATEC Web of Conferences 53, 01040 (2016)

4. V. Umanets, L. Kalitova, D.Kalitov, A. Chusov, E. Umanets, International Multidisciplinary Scientific GeoConference Surveying Geology and Mining Ecology Management, SGEM 1(5), 135-144 (2015)

5. A. Asadpoori, C. Ankomah, A. Asadpoori, O. Derevianko, E. Shaburov, MATEC Web of Conferences 193, 02039 (2018)

6. N.A. Politayeva, Y.A. Smyatskaya, V.V. Slugin, Comptes Rendus de L'Academie Bulgare des Sciences 71(6), 766-771 (2018)

7. N. Politaeva, Y. Bazarnova, Y. Smyatskaya, V. Slugin, V. Prokhorov, Journal of Industrial Pollution Control 33(2), 1617-1621 (2017)

8. Kh. V. Il'ina, N.M. Gavrilova, E.A. Bondarenko, M.Ju. Andrianova, A.N. Chusov, Magazine of Civil Engineering 76(8), 241-254 (2017)

9. A.V. Chechevichkin, N.I. Vatin, V.V. Samonin, M.A. Grekov, Magazine of Civil Engineering 76(8), 201-213 (2017)

10. E.N. Arakcheev, V.E. Brunman, M.V. Brunman, A.V. Konyashin, V.A. Dyachenko, A.P. Petkova, Gigiena i Sanitariya 96(2), 137-143 (2017)

11. A.P. Petkova, V.E. Brunman, M.V. Brunman, A.V. Konyashin, E.N. Arakcheev, Ecology and Industry of Russia 20(5), 10-15 (2016)

12. U. Saffiotti, Environmental Health Perspectives 47, 319-324 (1983)

13. L. Cizmas et al., Environmental Science and Technology 38, 5127-5133 (2004)

14. F. D. L. Leusch et al., Water Research 50, 420-431 (2014)

15. O.B. Ivanchenko, R.E. Habibullin, H.R. Husainova, Vestnik Kazanskogo tekhnologicheskogo universiteta 4, 157-163 (2006) 
16. O.B. Ivanchenko, R.E. Habibullin, Vestnik Kazanskogo tekhnologicheskogo universiteta 18, 433-436 (2015)

17. D. Novikov, L. Molodkina, A. Chusov, Y. Vedmetskii, Procedia Engineering 117(1), 264-272 (2015)

18. E. Simonenko, A. Gomonov, N. Rolle, L. Molodkina, Procedia Engineering 117(1), 342-349 (2015)

19. O.B. Ivanchenko, N.S. Karamova, R.E. Habibullin, Food Technology 4, 61-66 (2002)

20. Y. Han et al., Ecotoxicology and Environmental Safety 133, 448-456 (2016)

21. B. Jolibois, M. Guerbet, Mutation Research - Genetic Toxicology and Environmental Mutagenesis 565, 151-162 (2005)

22. A. A. Bakare, A. A. Okunola, O. A. Adetunji, H. B. Jenmi, Genetics and Molecular Biology 32, 373-381 (2009)

23. F. P. Rodrigues, J. P. F. Angeli, M. S. Mantovani, C. L. B. Guedes, B. Q. Jordão, Genetics and Molecular Biology 33, 169-175 (2010)

24. M. R. Thewes, D. E. Junior, A. Droste, Genetics and Molecular Biology, 34, 689-693 (2011)

25. B. Žegura, E. Heath, A. Černoša, M. Filipič, Chemosphere 75, 1453-1460 (2009)

26. F. D. L. Leusch et al., Water Research 50, 420-431 (2014)

27. D. M. Maron, B. N. Ames, Mutation Research/Environmental Mutagenesis and Related Subjects 113, pp. 173-215 (1983)

28. B.N. Ames, J. McCann, E. Yamasaki, Mutat Res. 31, 347-364 (1975)

29. Hakura A., Shimada H., Nakajima M., Sui H., Kitamoto S, Suzuki S., Satoh T. Mutagenesis. 20(3), 217-218 (2005)

30. L.M. Fonshtein, L.M. Kalinina, G.N. Poluhina, Medicina, 52 (1977)

31. L. Nylund,P. Einisto, Mutat. Res. 272 (3), 205-214 (1992) 